九州大学学術情報リポジトリ

Kyushu University Institutional Repository

\title{
A Synopsis of the Bee Genus Palaeorhiza Perkins (Hymenoptera, Colletidae) of New Guinea : Part VII. Subgenus Cercorhiza
}

Hirashima, Yoshihiro

Entomological Laboratory and Hikosan Biological Laboratory, Faculty of Agriculture, Kyushu University

https://doi.org/10.5109/23742

出版情報: 九州大学大学院農学研究院紀要. 26 (2/3)，pp.87-109，1982-02. Kyushu University バージョン：

権利関係 : 


\title{
A Synopsis of the Bee Genus Palaeorhiza Perkins (Hymenoptera, Colletidae) of New Guinea Part VII. Subgenus Cercorhiza*
}

\author{
Yoshihiro Hirashima \\ Entomological Laboratory, Faculty of Agriculture, \\ Kyushu University 46-01, Fukuoka 812 \\ and \\ Hikosan Biological Laboratory, Faculty of Agriculture, \\ Kyushu University 46-14, Hikosan, Fukuoka 824-07
}

(Received September 10, 1981)

\begin{abstract}
A new subgenus Cercorhiza is proposed for 11 species of Palaeorhiza of New Guinea and Solomon Islands, which is divided into 2 species groups. Eight new species, P. chimbuensis. nigrescens, terrestris, anthracina, melanosoma, dorsalis, sanguinea and pulchella, are described. P. terrestris is a ground nesting species. Visiting habits to Evodia of sanguinea and pulchella are noted.
\end{abstract}

In this paper a new subgenus Cercorhiza is proposed for 11 species of Palacorhiza of New Guinea and Solomon Islands, which is divided into 2 species groups. Eight new species, Palaeorhiza chimbuensis, nigrescens, terrestris, anthracina, melanosoma, dorsalis, sanguinea and pulchella, are described.

The new subgenus is characteristic in having the well developed caudal fimbria, pygidial plate and basitibial plate in the female in addition to the dense vestiture of hairs on the hind tibiae of female. These characters of female may suggest that the species of Cercorhiza are ground nesting in habits. As a matter of fact, P. gressittorum Hirashima and P. terrestris, new species, nest in the ground, so far as my observations go. The nesting habit of the former was reported by me in 1975 already (J. Fac. Agr., Kyushu Univ., 20: 40-41). I found the nesting site of $P$. terrestris on July 25, 1969 on the Bulldog Road $(2600 \mathrm{~m})$, $35 \mathrm{~km}$ SE of Wau, Papua New Guinea. Many females were nesting on the cliff gregariously.

Thus, it is very interesting to observe the morphological adaptation of Cercorhiza to nest in the ground is distinctive as in the subgenus Cnemidorhiza Hirashima (Esakia, No. 17, 1981) in which, however, the basitibial plate of female is absent but the dorsal face of the hind tibia of female is coarsely sculptured. These two subgenera are undoubtedly closely related. Unlike

* Contribution from the Entomological Laboratory, Faculty of Agriculture, Kyushu University, Fukuoka (Ser. 3, No. 103), and that from the Hikosan Biological Laboratory, Faculty of Agriculture, Kyushu University, Hikosan (Ser. 2. No. 48). 
Cnemidorhiza, the yellow marking is absent on the thorax of both sexes and the head of female in Cercorhiza.

\section{Cercorhiza, new subgenus}

Type-species : Palaeorhiza gressittorum Hirashima, 1975

The new subgenus is closely related to Cnemidorhiza Hirashima in the presence of the caudal fimbria and pygidial plate on the 6th tergum in the female but is separable from the latter in having the basitibial plate which is well developed on the hind legs of the female. In addition, the dorsal face of hind tibia of female is densely covered with usually long, rather coarse hairs. This vestiture is also unusual for Palaeorhiza.

The basitibial plate is well elevated with sharp margins; it is usually small but complete, but more or less obscure in chimbuensis, large and very conspicuous in gressittorum and nigrescens, large but the apical margin obscure in terrestris and anthracina. The corresponding portion of the male hind tibia is often provided with a small, slightly elevated disk. The caudal fimbria is dense, composed of well arranged, coarse, black or blackish hairs except chimbuensis in which it is whitish. The pygidial plate is also conspicuous with sharp edges, sometimes triangularly pointed at the apex.

The new subgenus is further distinct as follows:

Medium-sized to large, robust species; ground coloration of head and thorax variable, black, black and red, metallic and red, or metallic; pale marking absent on any part of thorax in both sexes and head of female; metasoma also variable, weakly to rather distinctly metallic, metallic and red, nearly entirely red or all black; pale markings of male head not well developed, confined to mandibles, labrum, clypeus, lower paraocular areas and scape; legs often reddened; wings usually distinctly darkened. Mandibles tridentate in female (except for terrestris in which dentation obscure with broad apical blade), bidentate in male; malar space variable in length, but less than basal width of mandible; scape of female long, usually free of hairs and shining, that of male moderate to long; male 1st flagellar segment longer than broad (although usually slightly so), about as long as 3rd except for concorda only (see below description); ocelli often rather large, the middle ocellus slightly smaller than posterior one; ocelloccipital space strongly slanting posteriorly. Collar of pronotum very thin dorsally in the middle ; scutellum well convex ; metanotum also moderately convex, slightly modified in terrestris and anthracina only (see below) ; propodeal enclosure large, smooth, shining, largely dorsal, often slightly concaved in the middle (Figs. 6 and 13) ; precoxal carina distinct and transverse in female, very strong in male; underside of thorax of male usually broad\& and deeply excavated; this portion sometimes well defined laterally by longitudinal carina and often covered with dense long hairs. Stigma and 2nd submarginal cell of wing usually large. Female fore tarsus with polliniferous hairs well developed, 2nd segment slightly longer than broad, only slightly larger than 3rd. Metasoma well convex dorsally; male 3rd and 4th sterna with or without elevations; male 5th sternum with a curled fringe of long, fuscous hairs on 
apical margin well developed, but poor in concorda only. Hairs variable; hairs on head and thorax long, dense, and black in gressittorum and nigrescens; sometimes hairs dense and fringe-like on latero-apical portions of 1 st tergum.

The subgenus may be divided into 2 species groups, as follows:

(1) The species group of gressittorum: Six species, chimbuensis, gressittorum, nigrescens, terrestris, anthracina, and melanosoma. Head and thorax black, not metallic; thorax broadly red in gressittorum only.

This species group may be further divided into 4 species subgroups, as follows :

(1-a) The species subgroup of chimbuensis: One species; male unknown. Metasoma with 3 basal segments red, 3 apical segments black with dark blue tint; head scanty of hairs, shining in front; thorax with short white hairs; malar space very narrow anteriorly; distance between clypeus and eye also short; caudal fimbria whitish; thorax very densely punctate, but punctures small, nearly dull; metasoma more or less well punctate, but punctures on 3rd tergum obscure; impunctate apical margins of 2 nd and $3 \mathrm{rd}$ terga broad, well marked, more broadened in the middle.

(1-b) The species subgroup of gressittorum: Two species, gressittorum and nigrescens. Mesoscutum, scutellum, axillae, metanotum, propodeal enclosure, pre-episternum and mesepisternum red in gressittorum; metasoma weakly metallic, but 1st segment red; head and thorax with dense, long, black hairs; basitibial plate conspicuous ; malar space slightly more than one-half as long as basal width of mandible in female, slightly shorter than the latter in male; supraclypeal area weakly convex, upper portion broad, flat, with sharp edges ; ocelli small ; mesoscutum and scutellum densely and coarsely rugosopunctate on roughened and dull ground; metasoma distinctly punctate; punctures on 3rd tergum very dense; apical impunctate margins of 2 nd and 3 rd terga very narrow; 3rd tergum of male with a pair of longitudinal elevations.

(1-c) The species subgroup of terrestris: Two species, terrestris and anthracina; male of the latter unknown. Hairs on head, mesoscutum and scutellum black or nearly so, those on the rest of thorax paler; metasoma weakly to distinctly metallic, with 1 st tergum sometimes piceous; malar space about as long as basal half of mandible; metanotum flat or slightly depressed in the middle basally and convex laterally; the depressed portion of metanotum densely punctate, punctures small; mandible of female terrestris nearly simple or only weakly tridentate ; basitibial plate large but incomplete ; metasoma distinctly punctate like the preceding species subgroup; underside of thorax of male deeply and broadly excavated; this portion well marked and densely covered with long pale hairs; sterna of male terrestris unmodified.

(1-d) The species subgroup of melanosoma: One species, male unknown. Metasoma black, shining, with 1st tergum partly reddened; head and thorax with long, dense hairs; hairs black on head, mesoscutum and scutellum, brownish on sides of thorax and paler on propodeum; malar space very narrow anteriorly; clypeo-ocular distance rather long, longer than in the species subgroup of chimbuensis; mesoscutum exceedingly densely punctate as in the latter; metasoma more or less well punctate, punctures on 3rd tergum very fine basally, 
becoming larger and coarser (although shallow) apically; impunctate apical margins of 2 nd and 3rd terga broad.

(2) The species group of concorda: Five species, concorda, dorsalis, rectituda, sanguinea and pulchella. Head and thorax weakly to distinctly metallic except for dorsalis in which mesoscutum, axillae and scutellum red; metasoma variable in color; hairs shorter, sparser and paler than in the species group of gressittorum, primarily white on sides of thorax and propodeum.

This species group may be divided into 3 species subgroups, as follows:

(2-a) The species subgroup of concorda: Two species, concorda and dorsalis; male of the latter unknown. Mesoscutum, axillae (not always) and metanotum red in dorsalis; metasoma distinctly metallic, shining; malar space very narrow in both sexes; mesoscutum and scutellum very densely punctate on microscopically roughened and dull ground; metanotum also well punctate, punctures on 3rd tergum dense, still distinct; impunctate apical margins of 2nd and 3rd terga narrow; 1st flagellar segment of male concorda shorter than broad, shorter than 2nd which is also shorter than borad; sterna of male concorda unmodified, strongly punctate; hair fringe on apical margin of 5 th sternum of male concorda poor; excavation of underside of male concorda not strong and not distinctly defined laterally.

(2-b) The species subgroup of rectituda: Two species, rectituda and sanguinea. At least 3 basal segments deep red in sanguinea; malar space short in female (female of rectituda unknown), long in male; mesoscutum and scutellum well punctate; metasoma very densely and finely punctate, punctures on 3rd tergum small and very dense; apical impunctate margins of terga linear; basitibial plate small, complete as in the preceding species subgroup; underside of thorax of male deeply and broadly excavated; this portion well defined by longitudinal ridges laterally; $3 \mathrm{rd}$ and 4 th sterna of male with various elevations.

(3-c) The species subgroup of pulchella: One species. Head and thorax distinctly metallic, shining; metasoma nearly all red; malar space narrow in female, slightly longer in male; punctures on metasoma more or less distinct but sparse; impunctate apical margins of terga more or less broad but not well marked; underside of male thorax considerably broadly and deeply excavated; this portion well marked and densely covered with long pale hairs; sterna of male unmodified.

Key to the species of Cercorhiza

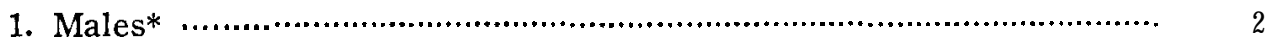

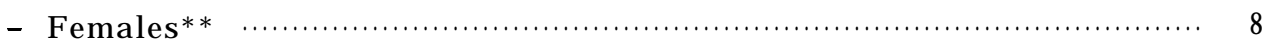

2. Head and thorax not metallic, black, or thorax red and black …........... 3

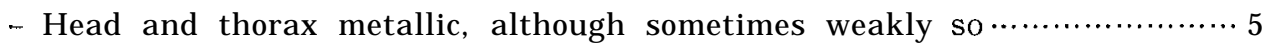

3. Mesoscutum, axillae, scutellum, metanotum, propodeal enclosure, pre-episternum and mesepisternum red, the rest of thorax black;

* Males of chimbuensis. melanosoma and dorsalis are unknown.

** Female of rectituda is unknown. 
head and thorax with dense long black hairs; legs red; metasoma metallic with 1 st segment red $\ldots \ldots \ldots \ldots \ldots \ldots \ldots \ldots \ldots$ gressittorum Hirashima

- Thorax entirely black

4. Hairs on head and thorax black; mesoscutum very densely punc. tate, entirely dull; metanotum broadly convex, as usual; 1 st metasomal segment red; 3rd sternum with a pair of longitudinal eleva-

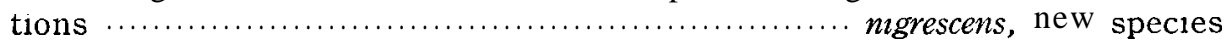

- Hairs on head, mesoscutum and scutellum black, those on the rest of thorax ochreous; mesoscutum densely punctate, weakly shining; metanotum broadly flat or slightly depressed in the middle, convex on lateral portions ; metasoma metallic, 1st tergum not red ; sterna normal; excavation on underside of thorax conspicuous, densely covered with pale hairs $\ldots . \ldots \ldots \ldots \ldots \ldots \ldots \ldots$ terrestris, new species

5. Head and thorax rather distinctly to distinctly metallic; metasoma

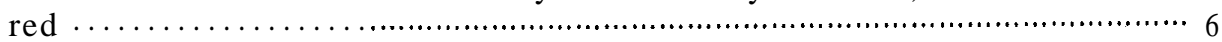

Head and thorax with metallic tint weaker; metasoma not red ….......... 7

6. Head and thorax shining green with slight brassy tint; metasoma nearly all red except apical portion dark with purple tint; legs red; hairs on propodeum and underside of thorax pale fulvous; underside of thorax broadly and deeply excavated; this portion well marked and covered with dense hairs; malar space about half the basal width of mandible in the middle; sterna normal; pale yellow markings on head not well developed ................pulchella, new species

- Head and thorax dark blue-green or more bluish; at least 3 basal segments of metasoma red; legs dark with large yellow markings; hairs on propodeum and underside of thorax silvery white ; excavation of underside of thorax also well marked, covered with white hairs; malar space about as long as basal width of mandible ; 3rd sternum with a pair of longitudinal elevations; similar but weaker and shorter elevations present on 4th sternum

sanguinea, new species

7. First flagellar segment longer than broad; malar space about twothirds as long as basal width of mandible; underside of thorax distinctly and broadly excavated; 3rd sternum with a pair of long, distinct elevations; similar but shorter elevations present on 4th sternum; 5th sternum with a curled fringe of long hairs on apical margin .......................................................... rectituda Cheesman

First flagellar segment shorter than broad, shorter than 2 nd which is also shorter than broad; malar space about one-third the base of mandible; excavation of underside of thorax weak and not well indicated; sterna unmodified, strongly punctate; apical fringe of hairs on 5th sternum poor; metasoma blue-green, shining, basal terga often piceous or more reddened with purple tint

concorda Cheesman

8. Thorax black and red or metallic and red ................................ 9

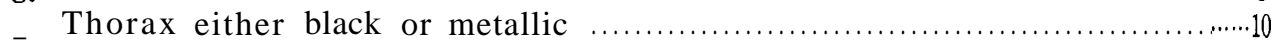


9. Mesoscutum, scutellum, axillae, metanotum, propodeal enclosure, pre-episternum and mesepisternum red, the rest of thorax black; head and thorax with dense long black hairs; 1st metasomal segment and legs red .......................................... gressittorum Hirashima

- Mesoscutum, axillae (not always) and scutellum red, the rest of thorax weakly metallic (dark blue-green) ; metasoma blue-green, rather shining, malar space short, about one-third the base of mandible ........................................................ dorsalis, new species

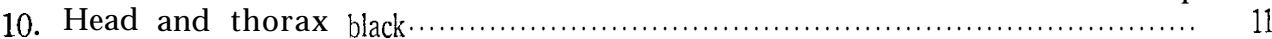

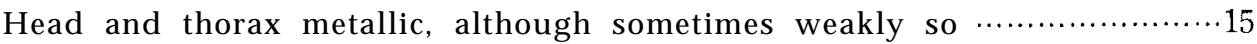

11. Metasoma with 3 basal segments red, 3 apical segments blackish with dark blue tint; hairs on head and thorax white; caudal fimbria whitish; impunctate apical margins of 2nd and 3rd terga broad, well marked, broadened in the middle; malar space very narrow anteriorly ............... chimbuensis, new species

- Metasoma not red; when 1st segment red or reddened, then head

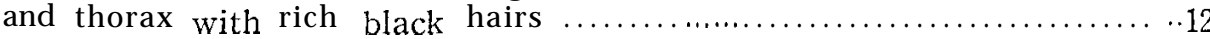

12. Metanotum broadly flat or slightly depressed in the middle basally, slightly convex laterally; malar space slightly more than half

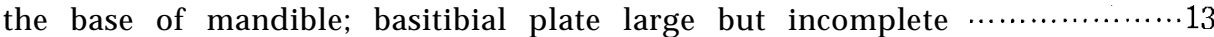

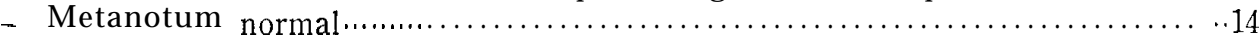

13. Mandible with a large apical blade, only slightly tridentate; upper swelling of supraclypeal area very distinct; mesoscutum densely, rather coarsely punctate, weakly shining; tegula dark ferruginous subhyaline ............................................... terrestris, new species

Mandible distinctly tridentate ; upper swelling of supraclypeal area low, but well marked (large, flat, with sharp lateral edges) ;mesoscutum exceedingly densely punctate on microscopically roughened and entirely dull ground; tegulae brown, not subhyaline

anthracina, new species

14. Head and thorax with dense, long, deep black hairs; malar space slightly more than half the base of mandible; 1st metasomal segment and legs red; metasoma very densely, rather finely punctate, apical impunctate margins of 2nd and 3rd terga very narrow nigrescens, new species

Hairs paler than in the preceding species, although those on head, mesoscutum and scutellum black (not deep black like nigrescens); malar space narrow, about one-third the base of mandible; 3rd tergum with punctures very fine basally, becoming larger and coarser (although shallow) apically; impunctate apical margin of 2nd and 3rd terga broad (but not sharply defined) ; metasoma black, without metallic shade .............................melanosoma, new species

15. Head and thorax weakly metallic; metasoma more metallic, bluegreen, shining; legs variable, dark or reddened; malar space short, about one-fourth the base of mandible; 3rd tergum densely punctate, punctures still distinct, with apical impunctate margin very 
narrow

concorda Cheesman

- Metallic tint on head and thorax stronger; metasoma red 16

16. Head and thorax strongly metallic, shining, blue-green with brassy and purple tints; matasoma red nearly all over with slight purple tint; hairs on propodeum ochreous or nearly pale fulvous; metasoma rather distinctly but sparsely punctate, impunctate apical margins of 2 nd and 3rd terga rather broad but not sharply indicated ... pulchella, new species

- Head and thorax dark steel-blue, rather shining; greenish tint on thorax; hairs on propodeum white; three basal terga deep red, the remaining terga blue-green or nearly so; metasoma very densely and rather finely punctate; 3rd tergum specially densely and finely punctate with apical impunctate margin linear.....

sanguinea, new species

(1) The species group of gressittorum

(1-a) The species subgroup of chimbuensis

\section{Palaeorhiza (Cercorhiza) chimbuensis, new species}

Unfortunately this is known by the type female only. This is very distinctive in having the head and thorax black, the basal three metasomal segments and legs red, and the caudal fimbria whitish. The malar space is shortest in the members of the gressittorum group. The basitibial plate is slender and not specially distinct in this species.

Female: Length about $8 \mathrm{~mm}$.

Relative head measurements: width, 36; length, 31; eye length, 26.5; upper interocular distance, 17; width of face, 23; lower interocular distance, 16; length of clypeus, 13. Malar space very narrow anteriorly, slightly widened posteriorly, about one-fourth the base of mandible in the middle; clypeoocular distance also short, but slightly longer than anterior length of malar space; supraclypeal area well convex but the upper swelling not distinctly elevated, rather rounded on lateral edges, gently reducing its height toward above; ocelli rather large; ratio of width of posterior ocellus to postocellar distacne to ocellocular distance to ocellocciptal distance as $7: 8: 10: 13$; preoccipital carina slightly reflected. Scutellum well convex. Second metasomal terga well convex in the middle, not constricted at base; pygidial plate pointed at apex.

Punctures: Head shining in front, with very weak and sparse punctures; thorax very densely punctate except propodeal enclosure, but punctures small on mesoscutum, and very small on sides of thorax; scutellum punctate as in posterior portion of mesoscutum; propodeal enclosure finely shagreened, nearly dull; metasomal terga well punctate but punctures not specially dense; punctures on 3rd tergum nearly obsolete; apical impunctate margin of 1st tergum rather broad, apical impuncatate margins of 2nd and 3rd terga broad, 
well marked, and broadened in the middle.

Color: Head and thorax black; flagellum reddish brown beneath. Wings more or less distinctly darkened distally; stigma fuscous; veins and tegulae brown. Legs red except for coxae, trochanters and femora of fore legs brownish. Metasoma with three basal segments red, the rest blackish with dark blue tint.

Pubescence: Hairs on head scanty, white even on vertex; hairs on thorax short, dense, silvery white ; hairs on hind tibia silvery; 1st tergum with small fringe of short, more or less dense, white hairs latero-apically; caudal fimbria whitish.

Type material: Holotype female (BISHOP 12404), Upper Chimbu Valley, $2200 \mathrm{~m}$, Papua New Guinea, 5. VII. 1955 (J. L. Gressitt).

Distribution: Papua New Guinea.

(l-b) The species subgroup of gressittorum

\section{Palaeorhiza (Gercorhiza) gressittorum Hirashima}

Palaeorhiza gressittorum Hirashima, 1975, J. Fac. Agr., Kyushu Univ., 20: 38, female and male. Papua New Guinea.

Very distinct species. Mesoscutum, scutellum, axillae, metanotum, propodeal enclosure, pre-episternum, mesepisternum, 1st metasomal segment and legs red, and the rest of body black having metallic tint on metasomal terga; head and thorax with long, dense, deep black hairs even on the underside of thorax ; basitibial plate of female conspicuous.

Distribution: High mountain regions of Papua New Guinea.

\section{Palaeorhiza (Cercorhiza) nigrescens, new species}

This is described based on 17 female and 15 male specimens. Morphologically this new species is very close to gressittorum but is separated primarily in having the thorax entirely black.

Type material: Holotype female (BISHOP 12405), 2 females and 6 males, Mt. Strong, north slope, 2600-3000 m, 8-10. I. 1968 (J. and M. Sedlacek) ; 12 females and 8 males, Mt. St. Mary, Papua New Guinea, 1900-3000 m, VII. 1968 (Mena, a native collector) ; 2 females and 1 male, Trapanas, $200 \mathrm{~m}$, Bougainveille, Solomon Islands, 27. II. 1968 (Tawi, a native collector).

Distribution: Papua New Guinea and Solomon Islands.

(l-c) The species subgroup of terrestris

\section{Palaeorhiza (Cerwrhiza) terrestris, new species}

This new species is described based on 28 female and 34 male specimens. This is a large, black species (metasoma weakly metallic and legs red) having long and dense hairs on the head and thorax. The hairs on head, mesoscu- 

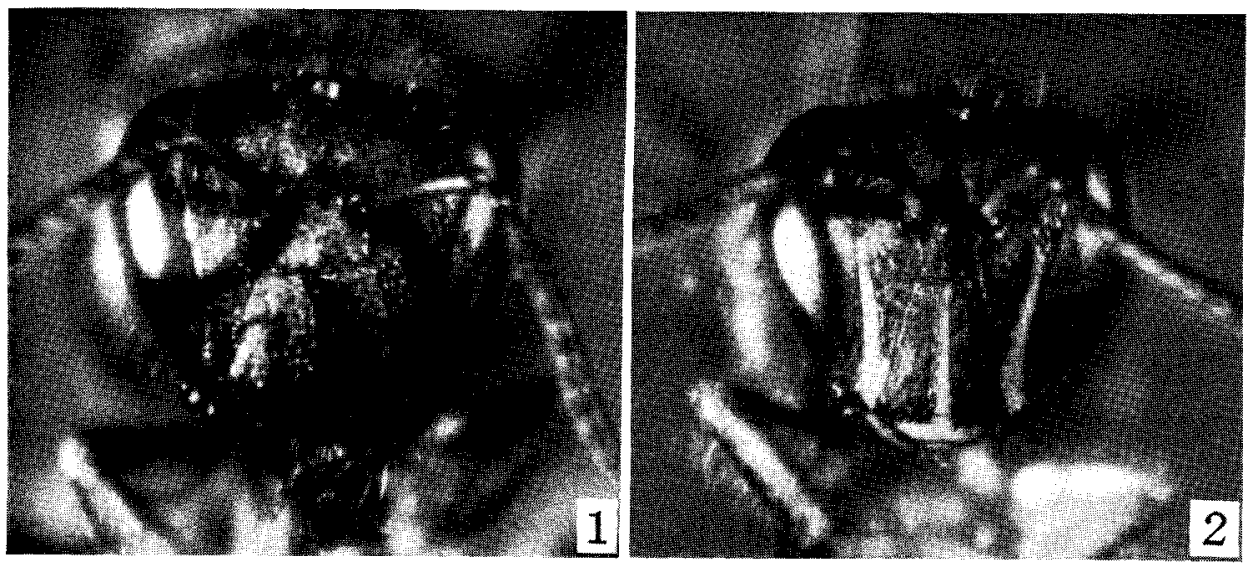

Figs. 1 and 2. Frontal view of the head of $P$. gressittorum Hirashima.

1: Female. 2: Male.

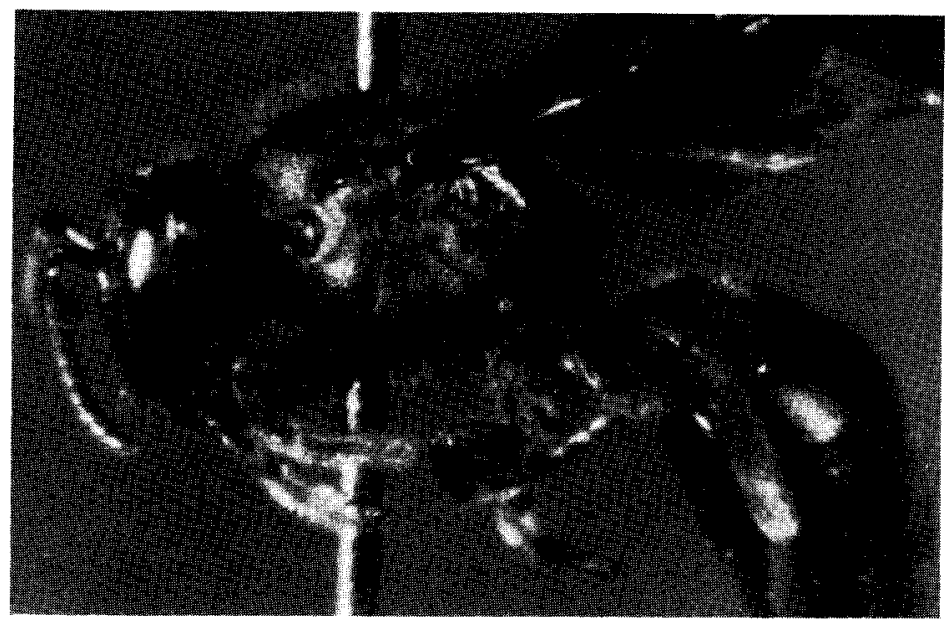

Fig. 3. Lateral view of the female of $P$. gressittorum Hirashima.

turn and scutellum black and those on the rest of thorax ochreous. The mandible of female is broad and nearly simple at apex. The modified metanoturn and incomplete basitibial plate are also characteristic to this species subgroup.

Female: Length about $10 \mathrm{~mm}$ (slightly over $10 \mathrm{~mm}$ in larger specimens).

Relative head measurements: width, 44; length, 37; eye length, 31; upper interocular distance, 23; width of face, 28.5; lower interocular distance, 22; length of clypeus, 16. Malar space long, about half as long as basal width of mandible in the middle ; clypeo-ocular distance about as long as malar space ; clypeus broadly nearly flat, although this area elevated as seen from side of head; upper swelling of supraclypeal area distinct, well dilated laterally with 

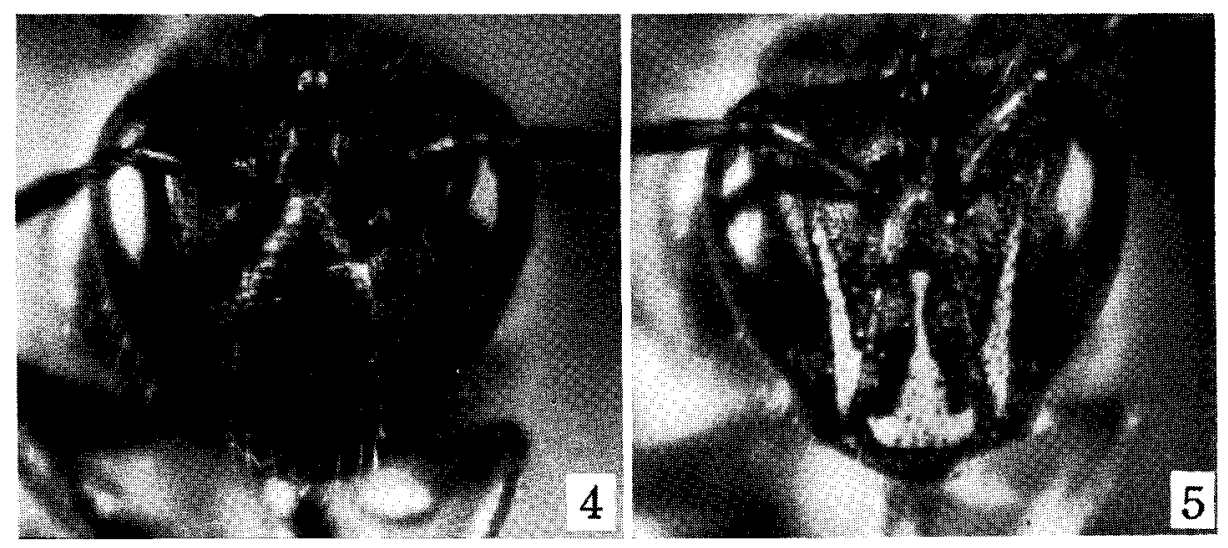

Figs. 4 and 5. Frontal view of the head of P.terrestris, new species. 4: Female. 5: Male.

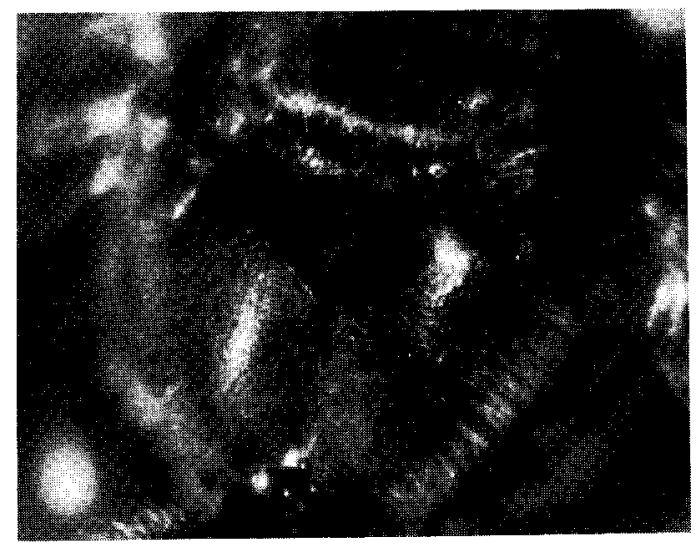

Fig. 6. Posterior part of the thorax of P.terrestris, new species, female, showing the propodeal enclosure.

sharp edges; ratio of width of posterior ocellus to postocellar distance to ocellocular distance to ocelloccipital distance as $8: 9: 17: 14$. Metanotum broadly flat or slightly depressed in the middle basally, slightly convex laterally. Basitibial plate large, incomplete. A pex of pygidial plate somewhat truncate.

Punctures: Head more or less distinctly punctate in front except for clypeus; the latter finely shagreened with sparse punctures irregular in size; mesoscutum rather coarsely, distinctly punctate, rather shining; punctures on scutellum slightly weaker than those on median portion of scutellum; punctures on median portion of metanotum very close and small; 1st tergum often transversely rugulose, densely punctate ; 2nd tergum densely punctate except for median portion smooth, shining, with sparse punctures; punctures on 
apical portion of 2nd tergum very fine and close; impunctate apical margin of 2nd tergum very narrow, well indicated, not broadened in the middle; punctures on 3rd tergum very dense, distinct; apical impunctate margin of 3rd tergum linear.

Color: Head and thorax black, with no metallic tint; apex of mandible and transscutal margin of mesoscutum red; metasoma black (sometimes piceous basally) with metallic tint variable, often dark blue-green with purple reflection. Legs red except for coxae and trochanters brownish. Wings distinctly darkened ; tegulae dark ferruginous subhyaline.

Pubescence: Head with black hairs, not dense in front; mesoscutum and scutellum with long, dense, black hairs; hiars on the rest of thorax ochreous;

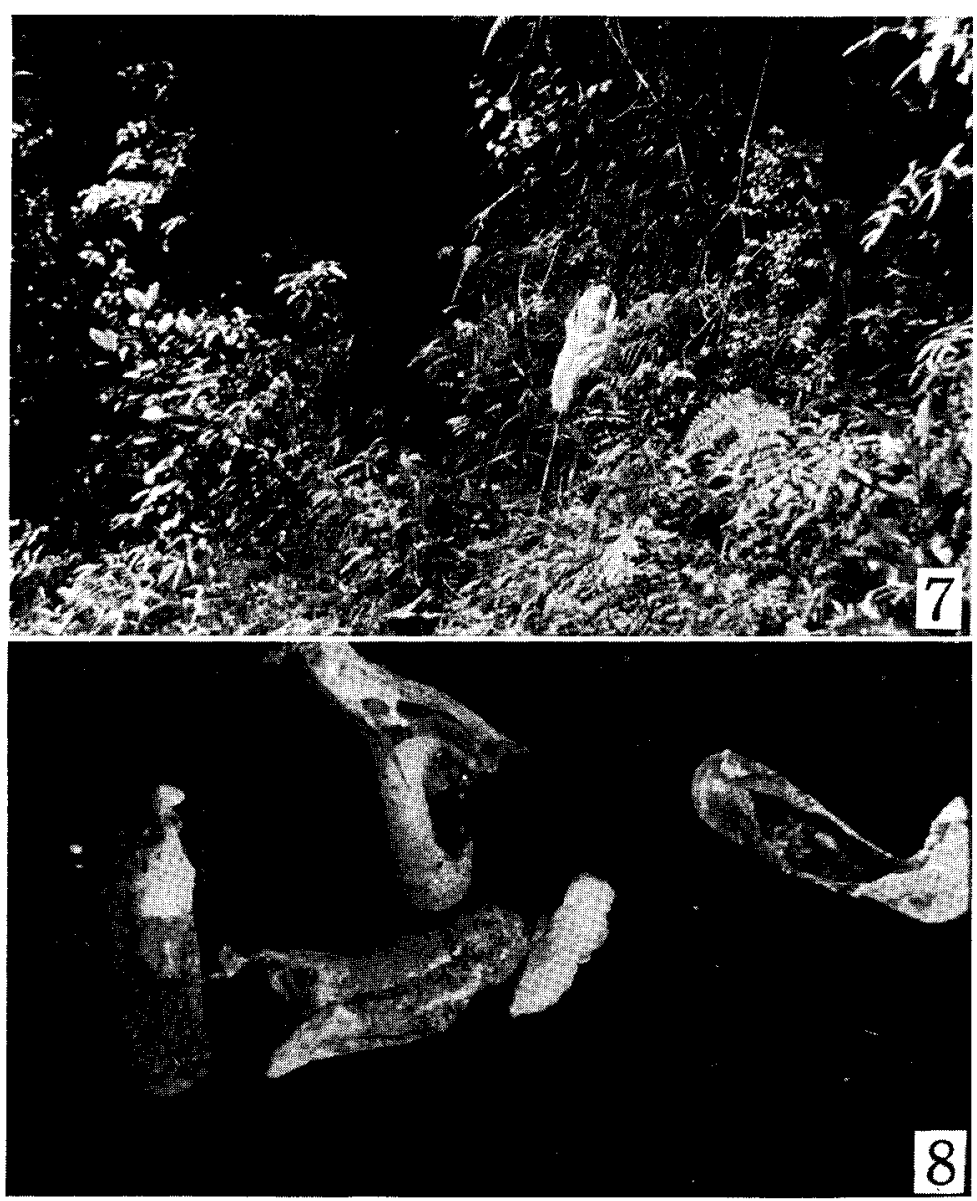

Fig. 7. Nesting site of P. terrestris, new species, on the Bulldog Road, 35 $\mathrm{km}$ SE of Wau, Papua New Guinea.

Fig. 8. Larva and pupa of P. terrestris, new species, together with larval cells which are made of cellophane-like material. 
ochreous hairs on latero-apical portion of 1st tergum somewhat dense and fringe-like; hairs on apex of metasoma black.

Male: Slightly smaller than female.

Relative head measurements: width, 41; length, 37; eye length, 30; upper interocular distance, 21; width of face, 25; lower interocular distance, 17.5; length of clypeus, 17. Differs from description of female as follows: Inner eye margins distinctly converging below ; malar space slightly shorter than basal width of mandible ; clypeo-ocular distance shorter than malar space; ratio of width of posterior ocellus to postocellar distatance to ocellocular distance to ocelloccipital distance as $8: 9: 14: 13$; scape moderately long, slightly curved; 1st flagellar segment slightly longer than broad, 2nd broader than long, 3rd a little longer than 1st. Precoxal carina very strong, stronger than in gressittorum and nigrescens; underside of thorax deeply and broadly excavated; this portion often marked by distinct edge laterally, and covered with dense long pale ochreous hairs. First tergum well convex; 2nd more convex and well elevating dorsally, constricted at base; sterna not modified.

Color: Metallic tint of metasoma slightly stronger than in female; stripe on mandible, mark on labrum, inverted $\mathrm{T}$ mark on clypeus (often broadened below, and top of which is reaching upper margin of clypeus), facial stripe below antenna and stripe on scape pale yellow.

Pubescence: Face hairy; hairs on head long, black but those on lower portion of genal area brown; fringe-like hairs on 1st tergum more distinct than in female; 5th sternum with a conspicuous fringe of long, dense, curled, brown hairs on apical margin.

Type material: Holotype female (BISHOP 12406), 23 females and 28 males, Bulldog Road, $2600 \mathrm{~m}$, at the nesting site, $35 \mathrm{~km}$ SE of Wau, Papua New Guinea, 25-26. VIII. 1969 (Y. Hirashima) ; 1 female and 1 male, Keglsugl, $2700 \mathrm{~m}$, Mt. Wilhelm, Papua New Guinea, 4. VIII. 1969 (Y. Hirashima).

Distribution : Papua New Guinea.

\section{Palaeorhiza (Cercorhiza) anthracina, new species}

Unfortunately this is known by the type female only. This is also a black species closely related to terrestris, but is separable from the characters mentioned below.

Female: Length about $10 \mathrm{~mm}$.

Relative head measurements: width, 43; length, 38; eye length, 30; upper interocular distance, 23; width of face, 28; lower interocular distance, 22; length of clypeus, 17. Differs from terrestris as follows: Mandible distinctly tridentate; clypeus less convex, more broadly flat; supraclypeal area with upper portion less convex, rather low, dilated laterally with sharp edges, more or less gently reducing its height toward above; mesoscutum and scutellum more densely punctate on more roughened and entirely dull ground, but punctures small, weaker than in terrestris; tegulae brown, not subhyaline ; legs brownish except for femora, tibiae and tarsi of hind legs red; 1st tergum not transversely rugulose; hairs on sides of thorax and propodeum paler, 


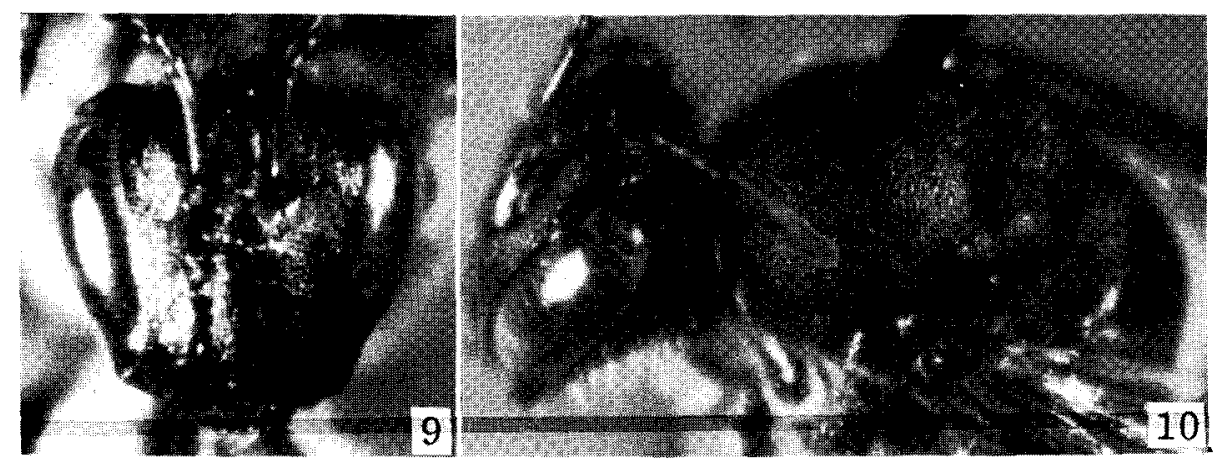

Figs. 9 and 10.P. anthracina, new species. 9: Frontal view of the head of female. 10: Dorso-lateral view of the head and thorax of female.

whitish.

Type material: Holotype female (BISHOP 12407), Goilala : Borne, 1950 m, Owen Stanley Range, Papua New Guinea, 16-30. IV. 1955 (W. W. Brandt).

Distribution : Papua New Guinea.

(1-d) The species subgroup of melanosoma

\section{Palaeorhiza (Cercorhiza) melanosoma, new species}

Unfortunately this is known by the type female only. This is very distinctive in having the metasoma black and not metallic in addition to the black head and thorax. The malar space is distinctly shorter than in the two preceding subgroups.

Female: Length about $9 \mathrm{~mm}$.

Relative head measurements: width, 39; length, 32; eye length, 25; upper interocular distance, 23; width of face, 26.5; lower interocular distance, 20; length of clypeus, 14. Inner eye margins rather distinctly converging below except for upper one-third which converges toward ocelli; malar space narrow,

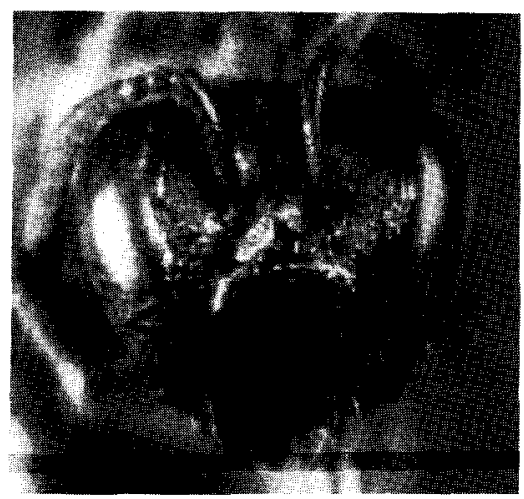

Fig. 11. Frontal view of the head of female of $P$. melanosoma, new species. 
about one-third as long as basal width of mandible in the middle (thus, malar space a little longer than in chimbuensis) ; clypeo-ocular distance rather long, distinctly longer than malar space, and distinctly longer than in chimbuensis; supraclypeal area moderately convex, upper portion slightly dilated laterally, not distinctly elevating, gently reducing its height toward above; ocelli moderate in size; ratio of width of posterior ocellus to postocellar distance to ocellocular distance to ocelloccipital distance as $6.5: 11: 17: 11$. Scutellum not well convex; broadly rather flat; precoxal carina rather weak. Basitibial plate large, well elevated (this portion somewhat worn out in the type specimen). Second tergum well convex in the middle, not constricted at base.

Punctures: Mesoscutum very densely rugoso-punctate on microscopically roughened and entirely dull ground, a feature similar to that of anthracina, but punctures a little smaller; scutellum slightly more coarsely punctate than in mesoscutum ; 1st tergum rather shining, microscopically lineolate, with microscopical, sparse punctures; 2nd tergum well punctate, punctures rather dense even on median portion; punctures on 3rd tergum very fine and dense at base, becoming larger and coarser (although shallow) toward apical portion; impunctate apical margins of 2nd and 3rd terga broad, well indicated at sides.

Color: Head black, shining in front; thorax black, dull or nearly so; metasoma black, shining. Legs reddened, partly brownish basally. Wings dusky; tegulae brown.

Pubescence: Black hairs on head long, rather dense, distinct even on frons; thorax also hairy; hairs on mesoscutum and scutellum black, long, those on the rest of thorax brownish but hairs on propodeum pale ochreous; hairs on metasoma black; no tergal hair fringe; hairs on legs pale.

Type material: Holotype female (BISHOP 12408), Upper Chimbu Kerowagi div., 2800 m, Papua New Guinea, 6. VII. 1955 (J. L. Gressitt).

Distribution : Papua New Guinea.

(2) The species group of concorda

(2-a) The species subgroup of concorda

\section{Palaeorhiza (Cercorhizu) concorda Cheesman}

Palaeorhiza concorda Cheesman, 1948, Ann. Mag. Nat. Hist., (12) :1: 324, female. New Guinea (Mt. Tafa).

This species was described by the type female only taken on Mt. Tafa (8500 ft.), Northern Territory, Papua New Guinea. I have seen the type of this species at the British Museum (Nat. Hist.) in 1967. The basitibial plate is well developed, with a few small punctures on the apical portion, but the lateral margins are not carinate. The pygidial plate is well carinate on the apical portion. I am not very sure, however, that whether my specimens from Mt. Wilhelm, on which the following description is based, exactly belong to concorda or not.

Female : Length 8-9.5 $\mathrm{mm}$ (the type about or less than $7 \mathrm{~mm}$ ). 
Relative head measurements: width, 38; length, 37; eye length, 26.5; upper interocular distance, 20; width of face, 24.5; lower interocular distance, 19; length of clypeus, 13. Malar space very narrow anteriorly, about onefourth the base of mandible in the middle, broadened posteriorly; clypeoocular distance narrow, but broader than malar space; clypeus broadly nearly flat, although this portion elevated when the head seen from side; supraclypeal area well convex, upper swelling dilated laterally, broad, somewhat gently reducing its height toward above; thus, upper portion of supraclypeal area more elevated than in gressittorum, less elevated than in terrestris, and more dilated laterally than in chimbuensis and melanosoma; ocelli moderate in size; ratio of width of posterior ocellus to postocellar distance to ocellocular distance to ocelloccipital distance as $7: 9: 13.5: 11$; ocelloccipital space very strongly slanting posteriorly from just behind posterior ocelli. Scutellum well convex; metanotum rather long (large) like gressittorum; propodeal enclosure large, slightly depressed in the middle; precoxal carina distinct. Basitibial plate well developed, punctate. Base of 2nd tergum not constricted.

Punctures: Face scanty of punctures which are not distinct even on upper portion of frons; mesoscutum very densely, more or less coarsely punctate on microscopically roughened and dull ground; scutellum punctate like mesoscuturn; metanotum also densely nearly rugoso-punctate but punctures very small; 1st tergum more or less well punctate with rather broad impunctate apical margin more broadened in the middle; 2nd tergum densely punctate except median portion, apical impunctate margin narrower than that of 1st; 3rd tergum very densely punctate nearly all over, with very narrow apical impunctate margin ; venter of metasoma strongly punctate.

Color: Head black with very slight purple tint on face and dark blue (or dark blue-green) shade on frons; thorax dark metallic blue with slight purple and green tints, not shining; metasoma weakly shining, dark green with delicate purple and brassy tints; two basal terga often broadly piceous or more reddened. Legs variable, dark with metallic tint or reddened or red (legs yellowish red in the type). Wings distinctly darkened; tegulae deep brown.

Pubescence: Hairs on head nearly black, but fuscous on genal areas; hairs on mesoscutum and scutellum blackish; those on the rest of thorax pale ochreous or whitish; hairs on apex of metasoma, including caudal fimbria, black or fuscous; no tergal hair fringe; hairs on legs paler, yellowish to whitish, but darker when legs dark.

$M$ ale: Slightly smaller than female.

Relative head measurements: width, 35; length, 30; eye length, 25.5; upper interocular distance, 18; width of face, 21; lower interocular distance, 13.5; length of clypeus, 13. Inner eye margins distinctly converging below; clypeus only slightly exceeding below beyond line tangential to lower margins of eyes; malar space very slightly longer than in female, about one-third the base of mandible; clypeo-ocular distance not long, but slightly longer than malar space; upper swelling of supraclypeal area well marked, but narrower than in female as usual for Palaeorhiza. Scape more or less long, curved; flagellum with 1st segment small, shorter than broad, a little shorter than 


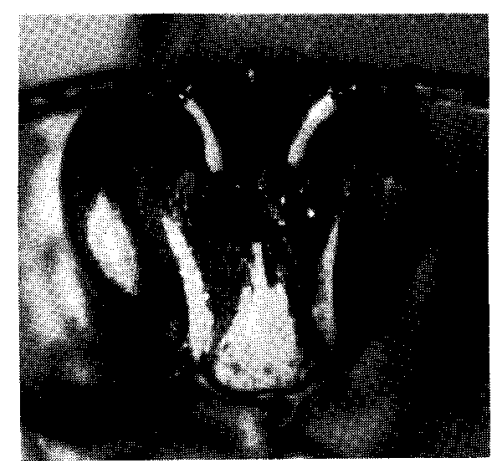

Fig. 12. Frontal view of the head of male of P.concorda Cheesman.

2nd which is also shorter than broad, 3rd longer than broad, slightly shorter than 1 st and 2nd combined (about $9: 11$ ). Scutellum more elevated than in female; precoxal carina long, distinct but not specially strong; underside of thorax slightly excavated, this portion not distinctly marked laterally. Metasomal sterna not modified, strongly punctate like female.

Punctures: First tergum with apical portion somewhat broadly impunctate in the middle only.

Color: Similar to female except pale markings on head, as follows: stripe on mandible, labrum, triangular mark on clypeus, facial stripe lateral to clypeus, and stripe on scape pale yellow; clypeal mark variable in shape; in one specimen out of seven, clypeus and face without pale marking; flagellum reddish brown or sometimes yellowish brown beneath; legs variable in color as in female, but with yellow markings; in one specimen metasoma red basally.

Pubescence: Hairs similar to female, but underside of thorax with rather dense, pale ochreous hairs and 1st tergum with more or less dense fringe of whitish or pale ochreous hairs on latero-apical margin; 5th sternum with apical fringe of brown hairs only poorly developed.

Specimens examined: 5 females and 7 males, Keglsugl, $2700 \mathrm{~m}$, Mt. Wilhelm, Papua New Guinea, 12. VIII. 1969 (Y. Hirashima).

Distribution : Papua New Guinea.

\section{Palaeorhiza (Cercorhiza) dorsalis, new species}

This species is described based on two female specimens. The new species is very close to $P$. concorda Cheesman, but mesoscutum and scutellum are red (axillae red in the paratype female). The legs are red in the holotype, dark in the paratype.

Type material: Holotype female (BISHOP 12409), Bulldog Road, $2350 \mathrm{~m}, 32 \mathrm{~km}$ S. of Wau, Papua New Guinea, 29 - 30. V. 1962 (J. Sedlacek) ; paratype female, Mt. Gilwe, $2550 \mathrm{~m}, 27$. V. -6. VI. 1963 (J. Sedlacek) ; both are taken by Malaise trap.

Distribution : Papua New Guinea. 
(2-b) The species subgroup of rectituda

\section{Palaeorhiza (Cercorhiza) rectituda Cheesman}

Palaeorhiza rectituda Cheesman, 1946, Ann. Mag. Nat. Hist., (12) 1: 322, male. Papua New Guinea (Mt. Tafa).

I have seen the type at the British Museum (Nat. Hist.) and found that the type is the male, not female as indicated in the original description.

Redescription of the type male: Length about $10 \mathrm{~mm}$.

Malar space about two-thirds (or about three-quarters) the base of mandible; clypeo-ocular distance about as long as malar space, much broader than width of scape; flagellum with 1st segment longer than broad and shorter than pedicel, 2nd broader than long, 3rd longer than broad and about as long as 1st; scutellum well convex, weakly bigibbous; underside of thorax broadly and deeply excavated; fore tarsi long; base of hind tibia with a raised disc which is corresponding to the basitibial plate of female; 3rd sternum ("the second" in the original description) with a pair of long, posteriorly converging, distinct elevations; 4th sternum with similar but shorter elevations, median portion between elevations roughly but shallowly punctate; apical fringe of fuscous hairs on 5 th sternum distinct.

Color: Head and thorax dark green, with slight purple tint which is somewhat evident on face and propodeum; stripe on mandible, labrum, inverted $\mathrm{T}$ mark on clypeus, lateral stripe (more or less broad) of face below antennae and stripe on scape pale yellow; legs piceous with very slight purple tint; anterior faces of femora and tibiae of fore and middle legs yellow; metasoma purple, with very slight green tint on 1st tergum ("abdomen blue-black" in the original description).

Pubescence: Hairs on head and thorax whitish, those on apical sterna brown.

Distribution : Papua New Guinea.

\section{Palaeorhiza (Cercorhiza) sanguinea, new species}

This is described based on 8 female and 3 male specimens. So far as the male is concerned, this is a relative of rectituda, but the ground coloration is much different. The fine and very dense punctation on the metasomal terga is one of the characteristics of this species.

Female: Length about $9 \mathrm{~mm}$.

Relative head measurements: width, 39.5; length, 33.5; eye length, 28; upper interocular distance, 20; width of face, 25; lower interocular distance, 20; length of clypeus, 14. Malar space narrow, less than half the base of mandible (or slightly over one-third) ; clypeo-ocular distance longer than malar space; clypeus largely flat, median portion slightly depressed above; supraclypeal area moderately convex with upper swelling broad, slightly dilated laterally with somewhat distinct edges, gently reducing its height toward 
above; a feature of supraclypeal area similar to that of concorda but less produced laterally; ratio of width of posterior ocellus to postocellar distance to ocellocular distance to ocelloccipital distance as $7: 9: 13: 15$. Scutellum well convex, not bigibbous; metanotum moderately convex. Basitibial plate small, but well developed with sharp margins. Metasoma well covex; 2nd tergum not constricted at base; pygidial plate small but distinctly carinate and acute at apex.

Punctures: Head below antennae nearly impunctate ; punctures on upper paraocular areas weak and shallow; mesoscutum rather coarsely and densely punctate on nearly smooth and shining ground, punctures small anteriorly, becoming larger posteriorly ; scutellum more densely and slightly more coarsely punctate than in the posterior portion of mesoscutum; metasomal terga very densely and finely punctate, but punctures sometimes sparse on median portion of 2 nd tergum; impunctate apical margins of 2 nd and 3 rd terga very narrow.

Color: Head and thorax metallic dark blue, with delicate dark brassy tint, more shining than in concorda; face below antennae with more or less distinct purple tint in some light; 3 basal segments of metasoma deep red, but sometimes base or more of 1st tergum dark and apical portion of 3rd metallic; sometimes 4 th sternum and base of 4 th tergum also red; apical metasomal segments often dark blue-green or more greenish. Wings dark but paler basally; tegulae deep brown with obscure metallic tint on anterior portions. Legs piceous, with tarsi reddened; fore tibiae with yellow mark in front basally.

Pubescence: Not hairy; hairs on head, mesoscutum and scutellum blackish, those on the rest of thorax white; no tergal hair band; hairs on apical portion of metasoma black; hairs on legs whitish.

Male: Similar to female in size.

Relative head measurements: width, 39; length, 35; eye length, 28; upper interocular distance, 18.5; width of face, 23.5; lower interocular distance, 18 ;
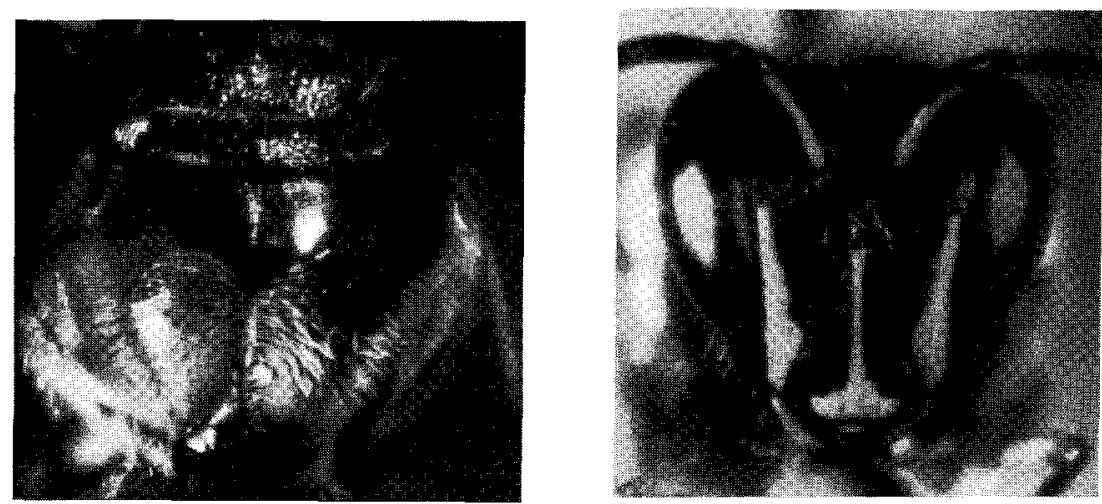

Fig, 13. Posterior part of the thorax of $P$. sanguinea, new species, female, showing the propodeal enclosure.

Fig. 14. Frontal view of the head of male of $P$. sanguinea, new species. 
length of clypeus, 16. Inner eye margins slightly converging below; malar space about as long as basal width of mandible; thus, malar space of male much longer than in female in this species; upper swelling of supraclypeal area moderate, rather small; ocellocular space slightly concaved; ratio of width of posterior ocellus to postocellar distance to ocellocular distance to ocelloccipital distance as $8: 8: 12: 15$. Scape long, longer than in concorda, curved; flagellum with 1st segment slender, slightly longer than broad, longer than 2nd which is broader than long, subequal to or a little longer than 3rd which is slightly longer than broad and a little shorter than 4th. Scutellum slightly more convex than in female; precoxal carina long, distinct; underside of thorax broadly and deeply excavated, well marked by distinct edge at side. First tergum rather large, well convex, subapical portion slightly depressed; 2nd tergum well convex medially, constricted basally; 3rd tergum with a pair of long, distinct, longitudinal keels and with a round elevation lateral to the keel; 4th sternum with two pairs of similar elevations, weak in smaller specimens.

Color: Head and thorax slightly more metallic than in female; head with following markings pale yellow: stripe on mandible, labrum, inverted $T$ mark on clypeus, the top of which is reaching the upper margin of clypeus, facial stripe below antennae, and stripe on scape; color of metasoma also similar to female; legs dark; tarsi reddish or yellowish red; anterior faces of femora and tibiae of all legs pale yellow, but yellow markings rather evanescent on hind legs.

Pubescence: Similar to female, but white hairs on latero-apical portions of 1st tergum more or less dense; apical fringe of long, curled, fuscous hairs on 5th sternum very distinct.

Type material: Holotype female (BISHOP 12410), Mt. Kaindi, $2360 \mathrm{~m}$, Papua New Guinea, 23. VII. 1969 (Y. Hirashima) ; 7 paratopotype females and 3 paratopotype males, July - August, 1969 (Y. Hirashima); two females and 1 male were taken on Evodia.

Distribution : Papua New Guinea.

(Z-c) The specis subgroup of pulchella

\section{Palaeorhiza (Cercorhiza) pulchella, new species}

This is described based on 3 female and 1 male specimens. This is a beautiful species having the head and thorax shining blue-green and the metasoma and legs red. The excavation on the underside of thorax of the male is most distinctive and well marked in the members of this subgenus.

Female: Length about $9 \mathrm{~mm}$.

Relative head measurements : width, 40; length, 35; eye length, 29; upper interocular distance, 19.5; width of face, 25.5; lower interocular distance, 21; length of clypeus, 15.5. Malar space oblique, narrow anteriorly, about onethird the base of mandible in the middle; clypeus broadly nearly flat, with an indication of median longitudinal ridge above; supraclypeal area not highly convex; upper swelling slightly dilated laterally, gently reducing its height 

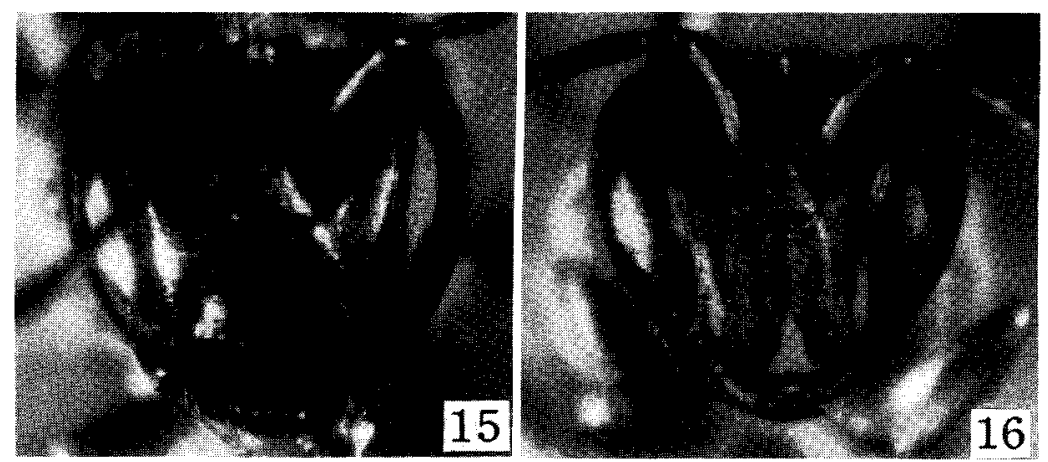

Figs. 15 and 16. Frontal view of the head of P. pulchella, new species. 15: Female. 16: Male.

toward above; this feature of supraclypeal area similar to sanguinea; ocelli rather large; ratio of width of posterior ocellus to postocellar distance to ocellocular distance to ocelloccipital distance as $8: 8: 12.5: 12$; ocelloccipital space strongly slanting. Scutellum well convex; propodeal enclosure large, weakly depressed in the middle; precoxal carina conspicuous; underside of thorax broadly and rather deeply concaved. Second tergum well convex medially, slightly constricted basally, apical margin well produced posteriorly in the median portion; pygidial plate rounded at apex. Basitibial plate large, nearly complete with weak apical edge, surface roughened. Stigma and 2nd submarginal cell of wing large.

Punctures: Head with very weak, sparse punctures; mesoscutum weakly and not densely punctate on smooth and shining ground, punctures sparser than in sanguinea; scutellum much more densely, subrugoso-punctate than in mesoscutum ;

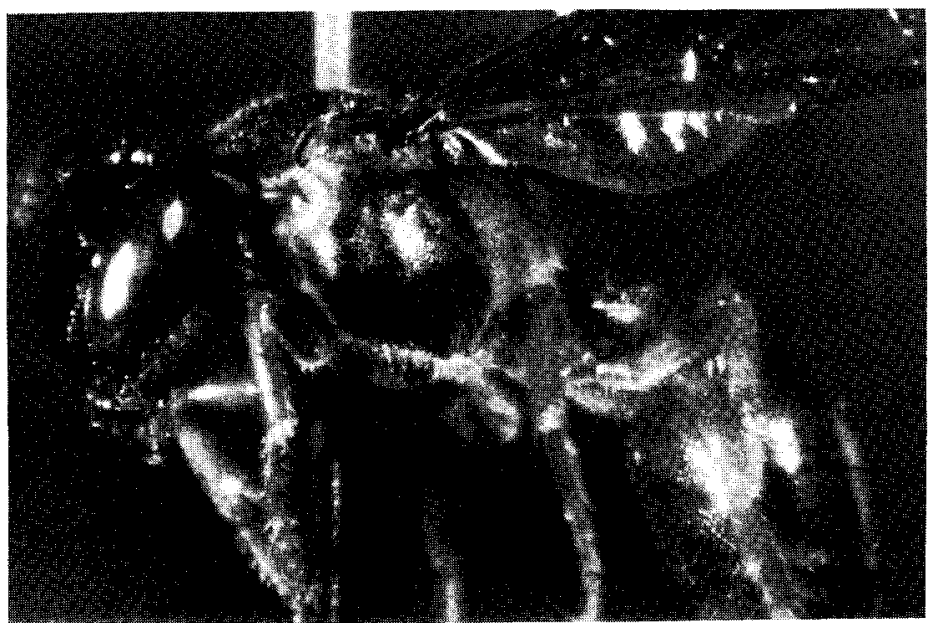

Fig. 17. Lateral view of the female of P. pulchellu, new species. 
1st tergum with more or less dense punctures; apical impunctate margin of 1st tergum more or less broad but not well marked; 2nd tergum rather sparsely punctate, punctures not strong but a little larger and much sparser than in sanguinea; 3rd tergum also not densely punctate; apical impunctate margins of 2nd and 3rd more or less well indicated, not broad.

Color: Head and thorax distinctly metallic, shining blue-green, with purple shade distinct in some light, especially on face; purple tint on mesoscutum distinct in the type female. Metasoma red; apical half of 5 th tergum and 6 th tergum only blackish with metallic tint. Legs yellowish red. Wings darkened, paler basally; tegulae ferruginous subhyaline.

Pubescence: Hairs on head scanty, slightly brownish ; hairs on thorax yellowish; no black hairs on mesoscutum and scutellum; no tergal hair fringe except rather dense white hairs on latero-apical portion of 1 st tergum.

Male: Similar to female in size.

Relative head measurements : width, 37 ; length, 33; eye length, 27; upper interocular distance, 17.5; width of face, 22.5; lower interocular distance, 17; length of clypeus, 15. Malar space slightly longer than in female, about half the base of mandible; clypeo-ocular space longer than malar space; upper swelling of supraclypeal area more elevated than in female, distinctly defined; ratio of width of posterior ocellus to postocellar distance to ocellocular distance to ocelloccipital distance as $8: 8: 11: 12$. Scape moderately long; flagellum with 1st segment only slightly longer than broad, about as long as 3rd; 2nd much broader than long. Precoxal carina strong, and this portion well convex; underside of thorax broadly and very deeply excavated; this portion well defined by ridge laterally, and densely covered with long, pale hairs. Sterna not distinctly modified but 2 nd and 3rd sterna each with a weak elevation

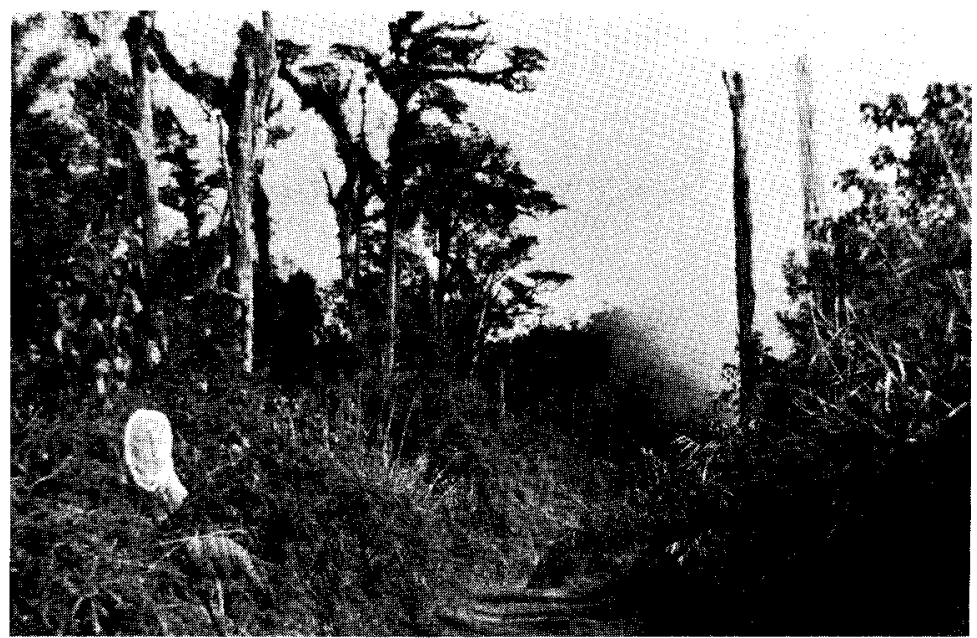

Fig. 18. A view of the summit of Mt. Kaindi, $2360 \mathrm{~m}$, near Wau, Papua New Guinea. 
on extreme lateral portion; similar but obscure elevation on lateral portion of 4 th.

Color: Similar to female but head with following markings pale yellow: stripe on mandible, spot on labrum, triangular mark on apex of clypeus, short facial stripe lateral to clypeus, and long stripe on scape.

Pubescence: Similar to female with hairs on apex of metasoma brown.

Type material: Holotype female (BISHOP 12411), Mt. Kaindi, $2360 \mathrm{~m}$, on Evodia, 24-25. IX. 1969 (Y. Hirashima) ; 1 paratopotype female, 22. VII. 1969 (Y. Hirashima) ;1 paratopotype male, 30. VII. 1969 (Y. Hirashima) ; 1 paratopotype female, 23. VIII. 1969, on Evodia (Y. Hirashima).

Distribution : Papua New Guinea.

\section{NOTE ON EVODIA VISITING HABITS OF PALAEORHIZA}

From July to September, 1969, I enjoyed collecting bees several times on the summit of Mt. Kaindi $(2360 \mathrm{~m})$. One of the views of this place is shown in Fig. 18. As can be seen from the photograph, this place belongs to the moss forest zone. Mist was observed at least once or twice a day, so far as my experience is concerned, even if it was fine. My impression was that Palaeorhiza rather abounds in this place. The individuals of some species, such as Palaeorhiza mandibularis Michener and Palaeorhiza conica Michener, were few, however. I collected most of Palaeorhiza on the flowers of Rubus.

Interestingly, however, I collected some of Palaeorhiza on the plant of Euodia which was growing on the edge of the road (Fig. 19). The plants were about $3 \mathrm{~m}$ high. It was curious to me that only one of them was frequently visited by Palaeorhiza. I was able to collect not a few specimens of three speceis of Palaeorhiza in one hour while I was waiting for them by the tree. The secret was that they visited the plant for the clear dew of tree fluid secreted near the top of the shoot (Figs. 20 and 21). Bees of Palaeorhiza supped the fluid as they alighted on the shoot. Thus, two species of Cercorhiza described in this paper, sanguinea and pulchella, were taken on Evodia. I am grateful to Dr. J. L. Gressitt for the identification of the plant.

I am also thankful to Dr. 0. Tadauchi of my laboratory for preparing the photographs shown in Figs. 7-8 and 18-21 from my transparencies. 


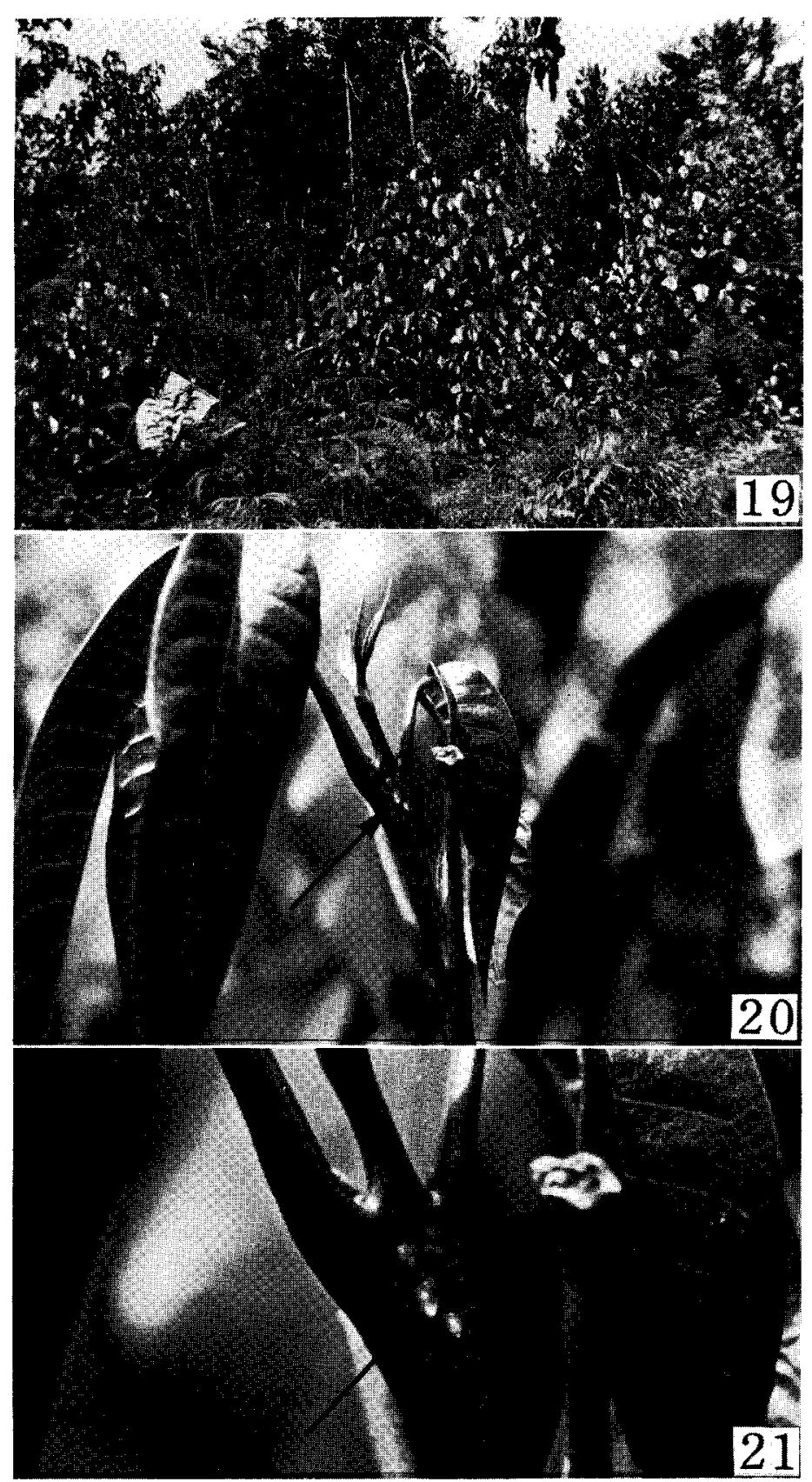

Figs. 19-21. A species of Evodia on the summit of Mt. Kaindi, which was visited by Palaeorhiza. 19: A view of two trees in the front. 20: Top of a shoot, showing a dew (pointed by an arrow) of tree fluid. 21: The siame. enlarged. 